\title{
The cultured rodent follicle as a model for investigations of gonadotrophin surge-attenuating factor (GnSAF) production
}

\author{
Paul A Fowler and Norah Spears ${ }^{1}$ \\ The Department of Obstetrics and Gynaecology, University of Aberdeen, Aberdeen, UK and ${ }^{1}$ The Department of \\ Biomedical Sciences, University of Edinburgh, Edinburgh, UK
}

Correspondence should be addressed to Paul Fowler; Email: p.a.fowler@abdn.ac.uk

\begin{abstract}
Gonadotrophin surge-attenuating factor (GnSAF) bioactivity (the suppression of GnRH-induced but not basal LH and FSH secretion from pituitary gonadotrophs) is produced by granulosa cells in vitro. Previous studies to investigate this bioactivity used dispersed granulosa cells which lack some cell types and the structural components of the follicle in vivo. The aim of this study, therefore, was to investigate whether intact rodent follicle culture was a suitable model for the study of the production of GnSAF bioactivity, allowing GnSAF to be investigated in a more physiologically realistic environment while still retaining culture conditions from which, as with granulosa cell cultures, extraneous factors can be excluded. Follicles from 16-day-old rats and 21-day-old mice were cultured for 3-6 days in the presence or absence of FSH and/or LH. The follicle-conditioned medium, and matching samples of unconditioned culture medium were added to our established rat pituitary monolayer GnSAF bioassay. Both mouse and rat intact follicles produced GnSAF bioactivity, reducing GnRH-induced LH secretion significantly. GnSAF output from the mouse follicles was highest during days 1-3 of culture, when follicles were at an early antral stage of development, and fell on days 4-6 as the follicles grew to the mid antral stage. While the stimulatory effects of FSH on rat follicle GnSAF secretion was dose-dependent, LH alone did not increase GnSAF production. An antibody against human GnSAF blocked GnSAF bioactivity produced by rat follicles, and recognised proteins within the expected pl and molecular weight range for GnSAF in two-dimensional gels of rat follicle-conditioned medium, showing a good homology between rodent and human GnSAF proteins. In conclusion, the release of GnSAF bioactivity is principally from small follicles stimulated by FSH. Therefore, intact rodent follicle culture systems offer an excellent model for the investigation of factors controlling GnSAF production under relatively physiological conditions.

Reproduction (2004) 127 679-688
\end{abstract}

\section{Introduction}

The putative ovarian hormone, gonadotrophin surgeattenuating factor (GnSAF) has the specific biological action of reducing pituitary secretion of luteinizing hormone (LH) and follicle-stimulating hormone (FSH) in response to gonadotrophin-releasing hormone $(\mathrm{GnRH})$. However, the factor remains to be conclusively identified (Fowler et al. 2003). GnSAF is secreted by granulosa cells (Fowler et al. 2002) and there is a large body of data demonstrating that FSH administration stimulates GnSAF production both in vivo (Messinis et al. 1993, 1994, Fowler \& Price 1997) and in vitro (Fowler \& Mason 2000). However, there are a number of concerns about both kinds of data. FSH treatment in vivo stimulates a considerable number of protein and gene changes within the ovary. Such changes in expression levels (e.g. in oestradiol and inhibin-B) can, in turn, exert effects at the level of the hypothalamus and pituitary, making it difficult to determine whether any effect of FSH on GnSAF is direct or indirect. On the other hand, FSH administration to cultured granulosa cells, while excluding the possibility of indirect effects, stimulates protein synthesis in the absence of normal structural relationships between granulosa cells and between granulosa, oocyte and thecal cells. There is the potential, therefore, for the response of cultured granulosa cells to deviate from the normal response to such stimulation in vivo.

Two publications have questioned a direct link between FSH and GnSAF. In the first, Tio et al. (1998) immunoneutralised $\mathrm{FSH}$ in female rats and concluded that there was no difference in circulating GnSAF. In the second, Schuiling et al. (1999) found that FSH treatment in female rats suppressed oestradiol-augmented $\mathrm{LH}$ responses to $\mathrm{GnRH}$ without affecting GnRH self-priming, a definite aspect of GnSAF from in vitro pituitary models (Fowler \& Templeton 1996). In both of these studies the interpretation of the 
data is complex and debatable, due to multiple factors operating in vivo. What is required is an analysis of FSH actions on the production of GnSAF from a model system demonstrating normal function in vitro. The intact rodent follicle model (Spears et al. 1994, McGee et al. 2001, Murray et al. 2001, Spears et al. 2002) retains the cellcell interactions and structural framework within which the granulosa cell normally functions.

The aim of this study was to investigate the relationship between follicle development, gonadotrophin exposure and GnSAF production in intact rodent follicle in vitro models. The mouse follicle model was initially investigated because follicular growth can be maintained to the late antral stage, allowing the production of GnSAF from both pre-antral and antral follicles to be investigated. However, this necessitates the presence of mouse serum in the culture medium which unfortunately renders it impossible to utilise a defined medium. Thus, the preantral rat follicle model was used to investigate gonadotrophin regulation of GnSAF production under highly controlled conditions. The fact that there are far fewer contaminating proteins in the culture medium makes the rat follicle culture model more suitable for the investigation of the regulation of GnSAF production.

\section{Materials and Methods}

\section{Animals}

Sprague-Dawley rats and $\mathrm{C} 57 \mathrm{BI} / 6 \times \mathrm{CBA} / \mathrm{Ca}$ F1 female mice were housed in an environmentally controlled room on a $12 \mathrm{~h}$ light: $12 \mathrm{~h}$ darkness photoperiod. Animals were provided with food and water which were available ad libitum.

\section{Follicle isolation and culture}

Mice and rats were killed by cervical dislocation and their ovaries removed to watch-glasses containing Leibovitz L-15 medium (Gibco-BRL, Renfrew, UK) supplemented with $3 \mathrm{mg} / \mathrm{ml}$ BSA (Fraction V, Sigma, Poole, Dorset, UK). Individual pre-antral follicles $(<200 \mu \mathrm{m}$ in diameter) were manually dissected using fine needles, randomly allocated to microtitre plates and cultured at $37^{\circ} \mathrm{C}$ in a water-saturated atmosphere of $5 \% \mathrm{CO}_{2} / 95 \%$ air mixture. Mouse follicles were placed in ' $U$ '-shaped wells of microtitre plates (Iwaki, Osaka, Japan) containing $30 \mu \mathrm{l}$ minimal essential medium (Gibco-BRL) overlaid with $75 \mu$ silicone fluid (Gibco-BRL; Merck, Poole, Dorset, UK). Culture medium for the mouse follicles was supplemented with 5\% mouse serum and $1 \mathrm{IU}$ recombinant human FSH (hrFSH) per $\mathrm{ml}$ (Serono-Ares, Geneva, Switzerland). Follicles were moved to fresh medium daily. Rat follicles were placed in polycarbonate membrane-lined flat-bottomed wells in $150 \mu \mathrm{l}$ minimal essential medium overlaid with $75 \mu$ silicone fluid. Rat follicle culture medium was supplemented with $3 \mathrm{mg} / \mathrm{ml} \mathrm{BSA}$ and ITS+ (insulin, $10 \mathrm{mg} / \mathrm{l}$; transferrin,
$5.5 \mathrm{mg} / \mathrm{l}$; linoleic acid, $4.7 \mathrm{mg} / \mathrm{l}$; selenium, $5 \mathrm{mg} / \mathrm{l}$; all from Sigma-Aldrich Company Ltd, Poole, Dorset, UK). Fifty percent of used medium was replaced with $50 \%$ fresh medium daily. hrFSH and/or recombinant human $\mathrm{LH}$ (hrLH) (Serono-Ares) were added as described below. A minimum of 12 follicles were cultured and assessed independently for every treatment in each follicle culture experiment.

\section{Quality control follicular fluid}

All protocols employing human subjects were given Joint Ethical Committee Approval at Aberdeen and patients all gave informed consent. Follicular fluid (hFF) was aspirated from follicles $\leq 18 \mathrm{~mm}$ in diameter from 40 women undergoing IVF in Aberdeen and pooled and desalted as previously described (Fowler et al. 2001). Subsequently, $500 \mu \mathrm{l}$ aliquots of these hFF pools were stored at $-20^{\circ} \mathrm{C}$ and used as a GnSAF bioactivity quality control (QC), producing a 40-60\% reduction in $\mathrm{GnRH}$-induced $\mathrm{LH}$ at $25 \mu \mathrm{l} /$ well, as previously described (Fowler et al. 2001). This preparation is subsequently referred to as QC hFF.

\section{GnSAF bioassay}

For each cell culture, 15 rats, selected at random during the oestrous cycle, were killed by stunning and cervical dislocation. Dispersion and culture of the pituitary cells was carried out as described in Fowler et al. (1994, 2002) and only preparations with $>75 \%$ viability of dispersed cells were used for bioassay. Primary pituitary cells were cultured at 30000 viable cells $/ 200 \mu$ l culture medium per well in 96-well tissue culture plates. The cells were cultured under sterile conditions for $24 \mathrm{~h}$ at $37^{\circ} \mathrm{C}$ in a watersaturated atmosphere of $5 \% \mathrm{CO}_{2} / 95 \%$ air mixture with serum-free defined culture medium (SFDM) as defined in Fowler et al. (1994). Media and non-attached cells were removed by aspiration and the wells were washed with $500 \mu \mathrm{l}$ SFDM. All experiments were then carried out on quadruplicate wells as follows: $200 \mu$ l fresh SFDM were added, together with the treatments made up to $25 \mu \mathrm{l}$ with SFDM. All the culture plates contained at least four control wells receiving SFDM only. After 24-h incubation with the test substances, the wells were washed with fresh medium and then treated with $0.1 \mu \mathrm{M}$ GnRH (Fertagyl; Intervet UK Ltd, Cambridge, Cambs, UK). Cultures were terminated after 4 -h incubation by collecting the media which were stored at $-20^{\circ} \mathrm{C}$ for determination of $\mathrm{GnRH}$ induced $\mathrm{LH}$ and $\mathrm{FSH}$ secretion.

\section{Dose-responses for assessment of bioactivities}

Doses of $0,1,5,25 \mu \mathrm{l} /$ well of rodent follicle-conditioned medium and QC hFF, with and without incubation with GnSAF antiserum, were added randomly to 5 independent rat pituitary cell cultures in quadruplicate wells. Each culture dish contained 4 control wells receiving SFDM only and 4 wells receiving $25 \mu \mathrm{l}$ SFDM instead of the $25 \mu \mathrm{l}$ $\mathrm{GnRH}$ challenge. This enabled the calculation of $\mathrm{LH}$ 
release in the absence of $\mathrm{GnRH}$ stimulation in order to ensure comparable $\mathrm{GnRH}$ responses from one culture to another. The QC hFF ensured that comparable detection of GnSAF bioactivity occurred across the different cultures. In all experiments, specific controls for each dose of gonadotrophin were samples of medium + gonadotrophin at the relevant doses, but without conditioning by rodent follicles. This design controlled for the exposure of the pituitary cells to FSH and $\mathrm{LH}$ where appropriate. Because the wells were washed prior to the $\mathrm{GnRH}$ challenge, the presence of $\mathrm{LH}$ or FSH during the treatment period could not artefactually elevate $\mathrm{LH}$ or FSH concentrations in the GnRH-treated samples.

\section{Two-dimensional gel electrophoresis}

Proteins in rat follicle-conditioned medium $( \pm F S H)$ were freeze-dried and resuspended at a ratio of $250 \mu \mathrm{l}$ unprocessed conditioned medium per $100 \mu \mathrm{l}$ lysis buffer (0.01 M Tris $-\mathrm{HCl}, \mathrm{pH} 7.4,1 \mathrm{mM}$ EDTA, $8 \mathrm{M}$ urea, $0.05 \mathrm{M}$ dithiothreitol (DTT), 10\% (v/v) glycerol, 5\% (v/v) NP40, $6 \%(\mathrm{w} / \mathrm{v}) \mathrm{pH} 3-10$ Resolyte (VWR International Ltd, Poole, Dorset, UK)). Following centrifugation at $11000 \mathrm{~g}$, the supernatant was stored at $-70^{\circ} \mathrm{C}$. Soluble proteins were analysed by two-dimensional gel electrophoresis (2D gels) gels using a small format gel system (Cash et al. 1997) with immobilised $\mathrm{pH}$ gradient (IPG) gels for the first dimension separation. Briefly, $40 \mu \mathrm{l}$ rat follicle-conditioned medium $( \pm \mathrm{FSH}$ ) containing $100 \mu \mathrm{g}$ total protein were adjusted to a final volume of $125 \mu \mathrm{l}$ in IPG re-swelling buffer (7M urea, $2 \mathrm{M}$ thiourea, $4 \%(\mathrm{w} / \mathrm{v})$ CHAPS, $0.3 \%(\mathrm{w} / \mathrm{v})$ DTT, $2 \%(\mathrm{w} / \mathrm{v}) \mathrm{pH} 4-8$ Resolyte). The proteins were separated in the first dimension using $7 \mathrm{~cm}, \mathrm{pH} \mathrm{4-7}$ IPG gel strips (Amersham Biosciences UK Ltd, Chalfont St Giles, Bucks, UK). The dehydrated IPG strips were rehydrated overnight in the IPG re-swelling buffer containing the conditioned media (Rabilloud et al. 1994). Following their re-hydration, the IPG gel strips were electrophoresed on a Multiphor II apparatus (Amersham Biosciences UK Ltd), the IPG gels were then equilibrated in buffer containing $50 \mathrm{mM}$ Tris- $\mathrm{HCl}, \mathrm{pH} 8.8,6 \mathrm{M}$ urea, $30 \%(\mathrm{v} / \mathrm{v})$ glycerol, $2 \%(\mathrm{w} / \mathrm{v})$ SDS, $1 \%(\mathrm{w} / \mathrm{v})$ DTT for $30 \mathrm{~min}$ followed by a second equilibration for $30 \mathrm{~min}$ in the same buffer $+2.5 \%(\mathrm{w} / \mathrm{v})$ iodoacetamide. The equilibrated strips were overlayed onto $7 \times 8 \mathrm{~cm} 10-15 \%$ gradient polyacrylamide slab gels and processed as described previously (Cash et al. 1999). Proteins were located by silver staining and Western blot. For the latter, gels were transferred onto $0.45 \mu \mathrm{m}$ nitrocellulose at $200 \mathrm{~V}$ for $75 \mathrm{~min}$ in transfer buffer $(0.25 \mathrm{M}$ Tris $-\mathrm{HCl}, 19.2 \mathrm{mM}$ glycine, $0.01 \%$ SDS, $2 \%$ methanol), washed in blocking buffer containing $2 \%$ non-fat powdered milk in Tris-buffered saline (TBS) for $45 \mathrm{~min}$ then washed for $3 \times 10 \mathrm{~min}$ in TBS containing $3 \mathrm{~g}$ Tris, $8 \mathrm{~g} \mathrm{NaCl}, 0.2 \mathrm{~g} \mathrm{KCl} / \mathrm{l}, \mathrm{pH} 8$ prior to incubation with GnSAF polyclonal antibody (pAb) at room temperature for $90 \mathrm{~min}$. The membranes were washed $(3 \times 10 \mathrm{~min}$, TBS + Tween $)$ and incubated with alkaline phosphatase-conjugated $\lg \mathrm{G}$ diluted in TBS for $90 \mathrm{~min}$. Recognised proteins were directly visualised with 5-bromo-4-chloro-3-indolylphosphate with nitroblue dimethyl formamide (Sigma-Aldrich Company Ltd).

\section{Hormone assays}

Concentrations of $\mathrm{LH}$ in cell-conditioned media from rat anterior pituitary cell cultures were determined using a homologous rat time-resolved fluoro-immunoassay (DELFIA) with sensitivity and intra- and interassay coefficients of variation values of $0.2 \mathrm{ng} \mathrm{LH} / \mathrm{ml}$ (NIDDK-rLH-RP3) using NIDDK-anti-rLH-S11 and $5.4 \%$ and $7.9 \%$ respectively.

\section{Experiments}

Experiment 1 was carried out on mouse follicles, using follicles dissected from 21-day-old mice. Five percent mouse serum was added to the medium. Subsequent experiments (experiments 2-5) were then carried out using a rat follicle culture model which supports follicle growth in the absence of serum (although BSA is still required in the culture medium). This allowed possible confounding effects of serum proteins on the culture system to be removed from the model. This culture system used follicles dissected from 12-day-old rats.

\section{Experiment 1: effect of duration of mouse follicle culture on GnSAF production}

Pre-antral mouse follicles were cultured for 6 days in culture medium. The medium was collected every $24 \mathrm{~h}$ and stored at $-20^{\circ} \mathrm{C}$ for subsequent bioassay. The aim of this experiment was to investigate how the profile of GnSAF production changed as follicles grew, from less than $200 \mu \mathrm{m}$ to around $400 \mu \mathrm{m}$ in diameter (Spears et al. 1994, 1998, 2002, Murray et al. 2001).

\section{Experiment 2: effect of duration of rat follicle culture on GnSAF production}

Pre-antral rat follicles were cultured in the presence or absence of $5 \mathrm{IU} \mathrm{FSH} / \mathrm{ml}$ for 3 days. The medium was collected daily and stored at $-20^{\circ} \mathrm{C}$ for subsequent bioassay. The aim of this experiment was to establish the pattern of GnSAF production over time in the presence and absence of FSH.

\section{Experiment 3: effect of gonadotrophins on GnSAF production by intact rat follicles}

(a) Pre-antral rat follicles were cultured in the presence of $0,0.5,1$, or $5 \mathrm{IU} \mathrm{FSH} / \mathrm{ml}$ for 3 days. The medium from the last $24 \mathrm{~h}$ was collected and stored at $-20^{\circ} \mathrm{C}$ for subsequent bioassay. The aim of this experiment was to investigate the $\mathrm{FSH}$ dose-response behaviour of rat follicles in terms of GnSAF production. (b) Pre-antral rat follicles were cultured in the presence of (i) no gonadotrophin, 
(ii) $5 \mathrm{IU} \mathrm{FSH} / \mathrm{ml}$, (iii) $0.5 \mathrm{IU} \mathrm{LH} / \mathrm{ml}$, (iv) $5 \mathrm{IU} \mathrm{LH} / \mathrm{ml}$, (v) $0.5 \mathrm{IU} \mathrm{LH} / \mathrm{ml}+5 \mathrm{IU} \mathrm{FSH} / \mathrm{ml}$ or (vi) $5 \mathrm{IU} \mathrm{LH} / \mathrm{ml}+5 \mathrm{IU}$ $\mathrm{FSH} / \mathrm{ml}$, for 3 days. The medium from day 2 was collected and stored at $-20^{\circ} \mathrm{C}$ for subsequent bioassay. The aim of this experiment was to investigate whether $\mathrm{LH}$ treatment affected GnSAF production both in the presence and absence of $\mathrm{FSH}$.

\section{Experiment 4: effect of anti-human GnSAF polyclonal antibody}

In order to investigate whether the GnSAF bioactivity produced by the rodent follicles was homologous to that produced by human granulosa cells and detected in human serum and hFF, an antibody bioactivity-blocking experiment was carried out as follows. Both the rat polycloncal antibody $(\mathrm{pAb})$ which previously blocked in vitro GnSAF bioactivity in human material (Fowler et al. 2002) and a rat $\mathrm{pAb}$ raised against whole serum from post-menopausal women (PMWS) and employed as a control antiserum in Fowler et al. (2002), were used. These antibodies were mixed gently at 1:1 in $100 \mu$ l aliquots with 2-day and 3day rat follicle-conditioned medium (obtained from follicles cultured in the presence of $5 \mathrm{IU} \mathrm{FSH} / \mathrm{ml}$ ), for $1 \mathrm{~h}$ at $37^{\circ} \mathrm{C}$ in 24-well dishes on an orbital shaker. The incubation experiment was repeated twice, combined and the resulting samples were bioassayed in two separate monolayer cultures. If the bioactivity produced by the rodent follicles had good homology with human GnSAF then we predicted that it would reduce apparent GnSAF bioactivity in rodent follicle-conditioned medium while the PMWS antiserum would have no effect since post-menopausal women do not produce GnSAF.

\section{Experiment 5: effect of FSH on the protein secretion profile of rat follicles}

Six rat follicles were cultured for 3 days both with and without $5 \mathrm{IU} \mathrm{FSH} / \mathrm{ml}$. For each treatment the media were collected and concentrated from $20 \mathrm{ml}$ to $1000 \mu \mathrm{l}$, desalted and dehydrated in a vacuum centrifuge. The two residues were resuspended in $250 \mu$ l of 2-D lysis buffer and electrophoresed using 2-D gels as outlined above.

\section{Statistical analysis}

The in vitro pituitary cell responses are expressed as percentages of the relevant control gonadotrophin concentrations secreted from wells on the same culture dishes. These controls were either wells exposed to SFDM alone (basal secretion) or wells exposed to SFDM $+0.1 \mu \mathrm{M}$ $\mathrm{GnRH}$. The differences between treatment groups and dose-responses were assessed using two-way analysis of variance (ANOVA). Differences between treatments and controls were tested by Dunnet's post hoc test and between treatments by the Bonferroni-Dunn post hoc test. The analyses were performed using the Statview 5 programme (Abacus Concepts Inc., Berkley, CA, USA). All results are presented as means \pm S.E.M. Since all bioassays were carried out in quadruplicate wells using two separate cell cultures, $n$ is stated as $2 \times 4$. For the rodent follicle growth curves $n \geq 12$ individual follicles.

\section{Results}

\section{Experiment 1: GnSAF production from intact mouse follicles}

When the secretory outputs of mouse follicles were followed over a 6-day period, there was marked GnSAF bioactivity production for the first 3 days of culture $(P<0.01-0.001:$ Fig. 1$)$, resulting in a marked drop in $\mathrm{LH}$ secretion at the $25 \mu \mathrm{l}$ conditioned medium/well dose. GnSAF production was highest on day 1 with even the $1 \mu$ l conditioned medium/well dose significantly reducing $\mathrm{GnRH}$-induced $\mathrm{LH}$ secretion $(P<0.001)$. Between days 4 and 6 of culture the stimulatory effect of the follicleconditioned medium increased, with GnRH-induced $\mathrm{LH}$ secretion increased to up to $180 \pm 16 \%$ of control, $P<0.01$ at $5 \mu \mathrm{l} /$ well. Thus during days $4-6$ of culture, decreases in LH secretion were only induced by the highest dose of conditioned medium/well.

\section{Duration of culture}

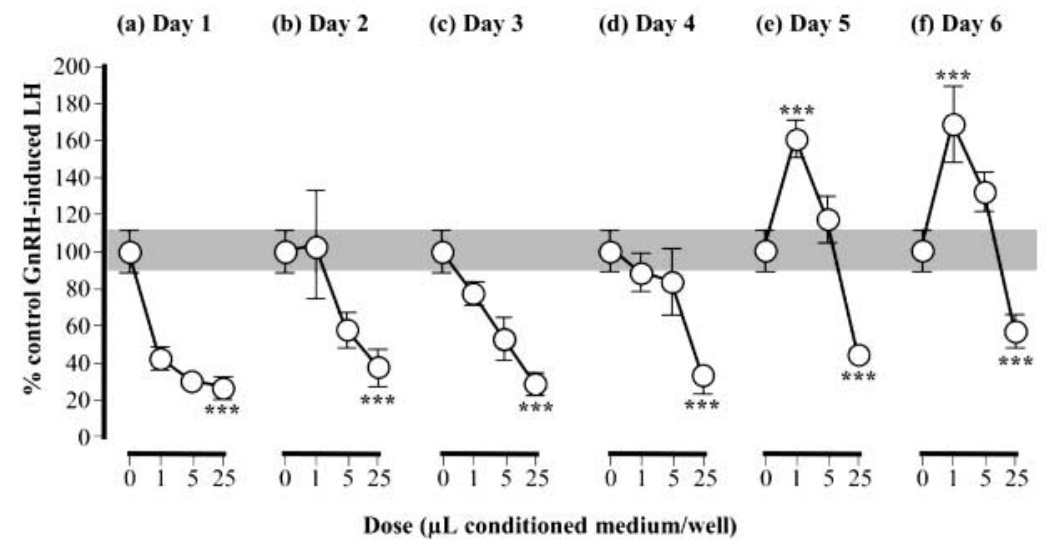

Reproduction (2004) 127 679-688
Figure 1 Intact murine follicles cultured for 6 days. GnSAF bioactivity production declines with the duration of culture from (a) day 1 to $(\mathrm{f})$ day 6 . The horizontal shaded bar denotes the mean \pm S.E. range for $\mathrm{GnRH}$-induced $\mathrm{LH}$ secretion in the presence of medium only. Data represent the mean of two different rat pituitary cell culture bioassays for each dose-response curve. Significance values are by ANOVA relative to controls (culture medium only), $* * P<0.01, * * * P<0.001$. Data are shown as means \pm S.E., $n=2 \times 4$. 


\section{Experiment 2: GnSAF production from intact rat follicles}

As previously documented (McGee et al. 1997, 2001), this serum-free culture system supported the growth of follicles in the presence of $\mathrm{FSH}$, although no antral development was seen in this or in subsequent rat follicle culture experiments. FSH stimulated increased GnSAF production by rat follicles (Fig. 2). In the absence of FSH there was only detectable GnSAF production by the follicles on day 1 of culture $(P<0.05)$. In contrast, FSH treatment stimulated GnSAF production on both days 1 and 2 of culture $(P<0.01$ and $P<0.05$ respectively). Although there was a statistically significant decline $(P<0.05)$ in GnSAF

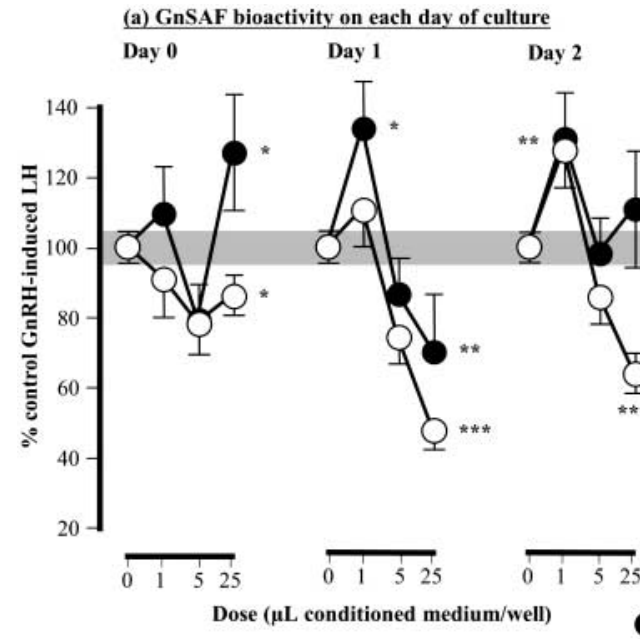

Control (b) Rat follicle growth during culture period

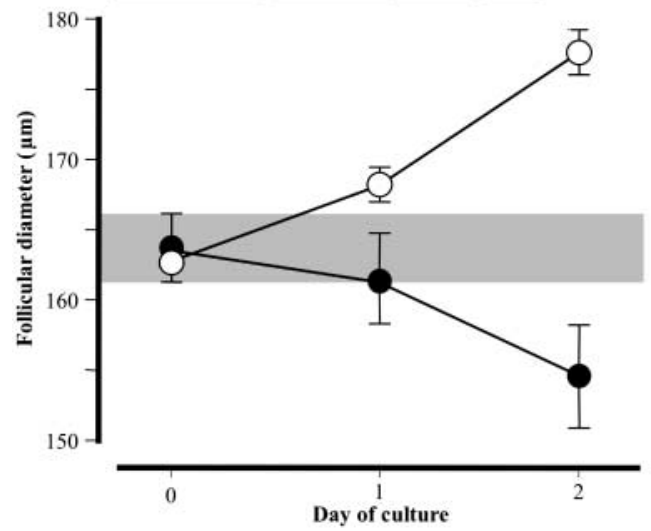

Figure 2 Intact rat follicles cultured in the presence or absence of 5 IU FSH/ml for three days. (a) Peak GnSAF bioactivity production was seen on day 1 of culture, coincident with (b) moderate follicular growth. The horizontal shaded bars denote (a) the mean \pm S.E. range for $\mathrm{GnRH}$-induced $\mathrm{LH}$ secretion in the presence of medium only or (b) the mean \pm S.E. range for follicle diameter at the start of the experiment. Data represent the mean of two different rat pituitary cell culture bioassays for each dose-response curve. Significance values are by ANOVA relative to controls (culture medium only), $* P<0.05, * * P<0.01, * * * P<0.001$. Data are shown as means \pm S.E., $n=2 \times 4$. production as the follicles grew from around 170 to $180 \mu \mathrm{m}$ in diameter, this difference was reflected in an $8 \%$ difference in the suppression in $\mathrm{GnRH}$-induced $\mathrm{LH}$ secretion at the highest dose of conditioned medium. These findings show that GnSAF production by rat follicles occurs in the presence of FSH and suggest that this occurs primarily in smaller follicles, as in the mouse.

\section{Experiment 3: effect of gonadotrophins on GnSAF production by intact rat follicles}

Experiment 3a showed that the stimulatory effect of FSH on GnSAF bioactivity was dose-dependent, while no such effect was seen on follicle growth (Fig. 3). All FSH doses stimulated follicle growth over a 3-day period $(P<0.001)$. In the absence of $\mathrm{FSH}$, follicle diameter fell slightly over the course of the culture $(P<0.05)$. GnSAF production on day 2 was stimulated most by $1 \mathrm{IU} \mathrm{FSH} / \mathrm{ml}$ $(P<0.001)$, a significantly greater production than that of other doses $(P<0.05)$, although there was no difference between the growth rates of any of the follicles grown in the presence of $\mathrm{FSH}$. In contrast, experiment $3 \mathrm{~b}$ showed that $\mathrm{LH}$ alone (at both 0.5 and $5 \mathrm{IU} / \mathrm{ml}$ ) had no significant effect on GnSAF secretion (Fig. 4a) and that these follicles did not grow over the culture period (Fig. 4b). The presence of FSH stimulated growth $(P<0.01)$, as in experiment $3 \mathrm{a}$, although growth was unaffected by the additional presence of $\mathrm{LH}$. Co-treatment of $\mathrm{LH}$ with $5 \mathrm{IU}$ $\mathrm{FSH} / \mathrm{ml}$ did, however, further increase GnSAF bioactivity significantly at the $5 \mu \mathrm{l}$ conditioned medium/well dose $(P<0.05)$.

\section{Experiment 4: nature of GnSAF secreted by intact rat follicles}

Neither the pAb raised against GnSAF or the pAb raised against serum from post-menopausal women had any effect on GnRH-induced LH secretion in the absence of rat follicle-conditioned medium. When rat follicle-conditioned medium from both 2 and 3 days of culture was incubated with the two rat pAbs (Fowler et al. 2002), the $\mathrm{pAb}$ raised against human GnSAF completely blocked GnSAF bioactivity. In contrast, following incubation with the rat pAb raised against serum from post-menopausal women, GnSAF bioactivity remained unchanged $(P<0.01)$ (Fig. 5). This suggests that there is relatively close homology between rodent and human GnSAF.

\section{Experiment 5: effect of FSH on the protein secretion profile of rat follicles}

The production of proteins by the rat follicles was further investigated by comparing silver-stained 2-D gels of medium conditioned in the presence and absence of FSH (Fig. 6a,b). Since the culture medium had to be supplemented with BSA to support follicle health, heavily stained areas coinciding with the established position of serum albumin were obvious. Despite this, the FSH could 
(a) GnSAF bioactivity following FSH treatment

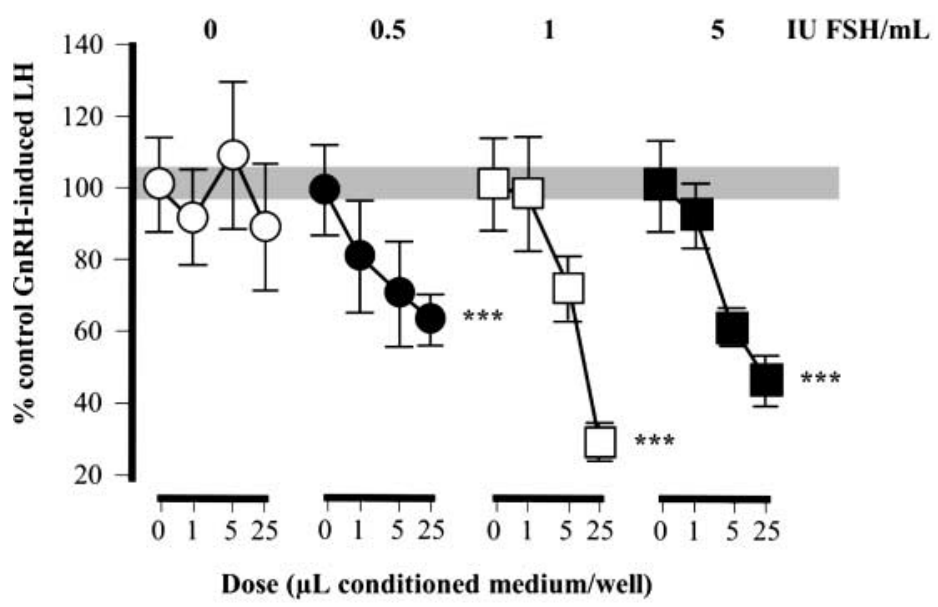

(b) Rat follicle growth during culture period

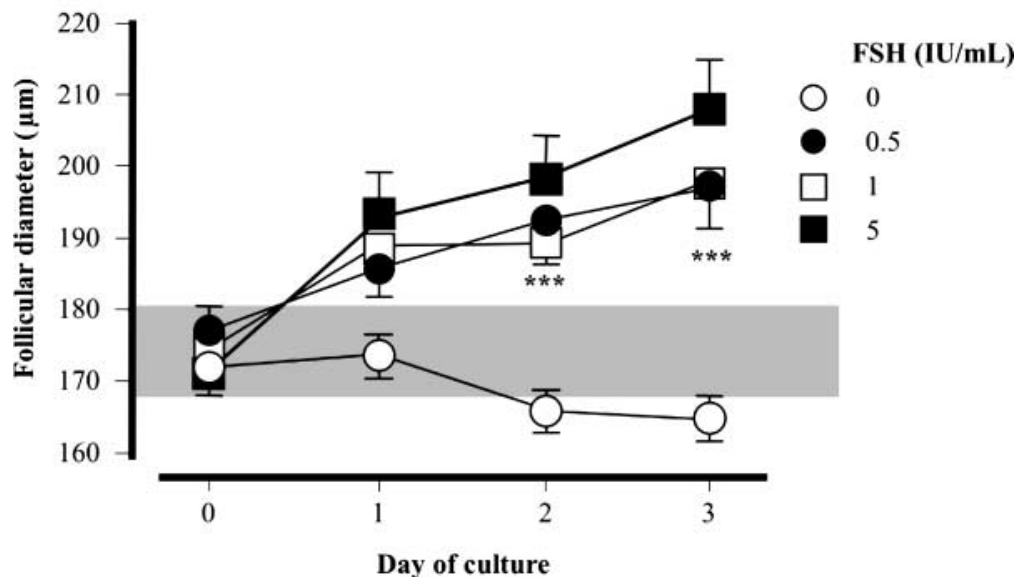

Figure 3 Intact rat follicle culture: pre-antral rat follicles were cultured in the presence of $0,0.5,1$ or 5 IU FSH/ml for three days. (a) Peak GnSAF bioactivity production was seen by treatment with $1 \mathrm{IU} \mathrm{FSH} / \mathrm{ml}$ as assessed on day 2 of culture, compared with similar effects of FSH on (b) follicle growth. The horizontal shaded bars denote (a) the mean \pm S.E. range for $\mathrm{GnRH}$-induced $\mathrm{LH}$ secretion in the presence of medium only or (b) the mean \pm S.E. range for follicle diameter at the start of the experiment. Data represent the mean of two different rat pituitary cell culture bioassays for each dose-response curve. Significance values are by ANOVA relative to controls (culture medium only), $* * * P<0.001$. Data are shown as means \pm S.E., $n=2 \times 4$. clearly be seen to both stimulate and inhibit a range of protein spots. When probed with the anti-human GnSAF pAb in a Western blot (Fig. 6c), several proteins in a band between 50 and $65 \mathrm{kDa}$ and between 4.5 and $5.5 \mathrm{pH}$ were stained - an area similar to that observed when this antiserum was used to Western blot human granulosa cell-conditioned medium (Fowler et al. 2002). These Western blot-recognised protein spots matched several less abundant spots that increased with FSH treatment but are not highlighted in Fig. $6 \mathrm{~b}$ in order to retain clarity. Unfortunately, the protein yield was not sufficient for any of the up-regulated protein spots to be excised and subjected to peptide mass mapping.

\section{Discussion}

This study clearly shows that, in the in vitro intact rodent follicle model, GnSAF production is FSH dependent and is highest in early antral follicles. These findings closely match data for other species, in particular the human, both in vivo and in vitro (for reviews see Fowler \& Templeton 1996, Fowler et al. 2003).

Follicles produced GnSAF only if cultured in the presence of $\mathrm{FSH}$, the presence of $\mathrm{LH}$ alone being insufficient to induce its production. Since $\mathrm{FSH}$, but not $\mathrm{LH}$, is required for antral follicle survival in mice (Spears et al. 1998), the lack of GnSAF production in the absence of $\mathrm{FSH}$ is likely to be due to the induction of granulosa cell apoptosis in these follicles (Baker et al. 2001). Similarly, McGee et al. (1997) demonstrated increased apoptosis in cultured pre-antral rat follicles (using the same culture method as in these experiments), while Wang et al. (2003) showed that FSH is essential to protect early antral rat follicles from apoptosis. While the inability of $\mathrm{LH}$ to induce GnSAF production in the absence of FSH could be an indirect effect due to atresia in these follicles, we also showed that $\mathrm{LH}$ was unable to stimulate increased GnSAF production in the presence of FSH. The follicles in these experiments remained at the pre-antral stage throughout the culture period, and it is possible that these follicles 
(a) GnSAF bioactivity following gonadotrophin treatment

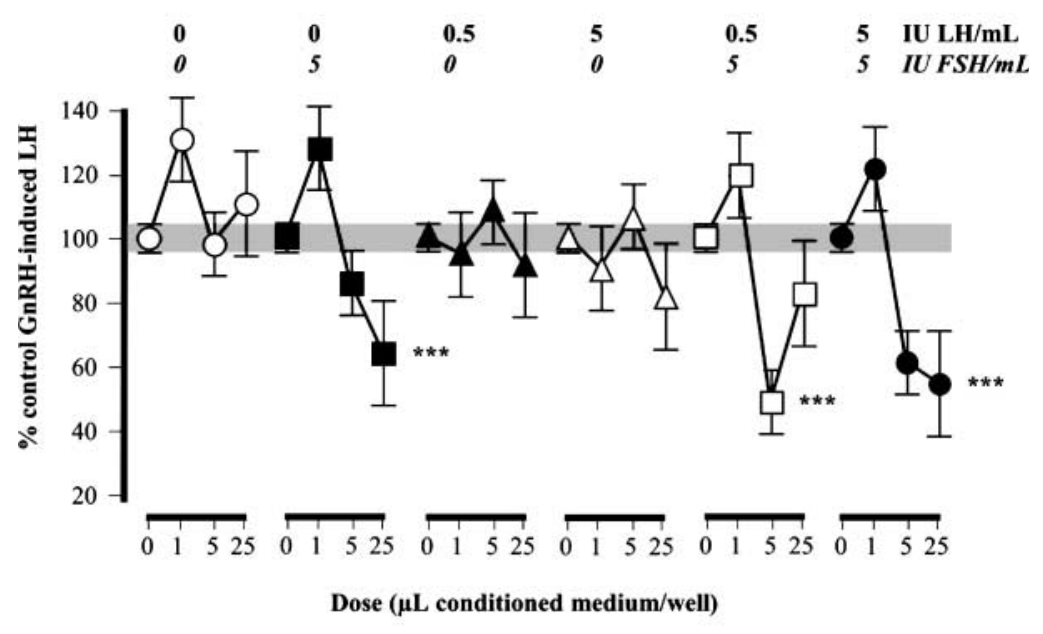

(b) Rat follicle growth during culture period

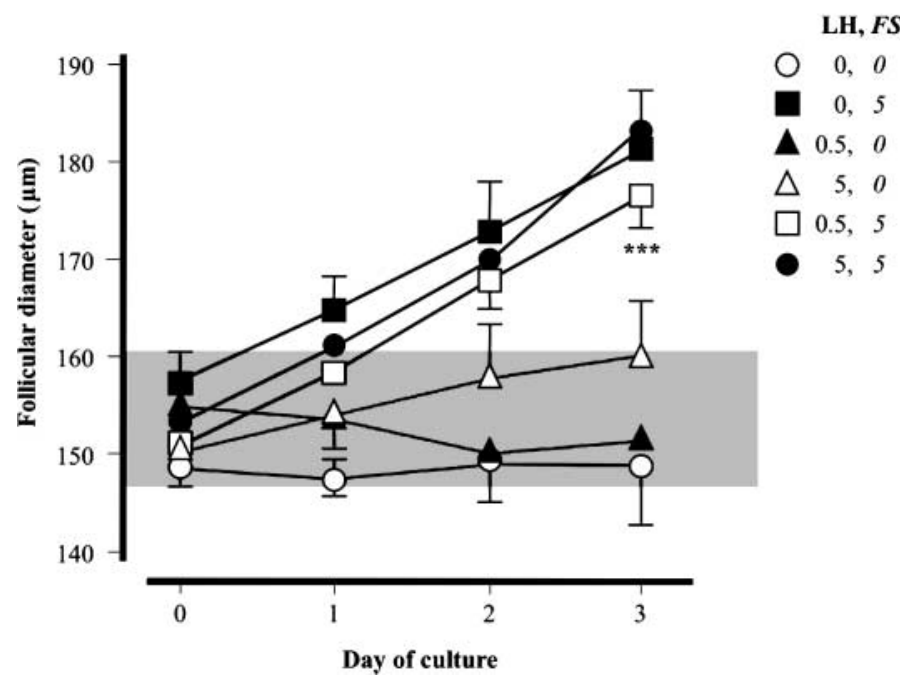

Figure 4 Intact rat follicle culture: pre-antral rat follicles were cultured in the presence of various doses of gonadotrophins. (a) Moderate augmentation of GnSAF bioactivity production by combined $\mathrm{LH}$ and FSH treatment was seen on day 3 of culture, although the effects of $\mathrm{LH}$ on (b) follicle growth were slight. The horizontal shaded bars denote (a) the mean \pm S.E. range for $\mathrm{GnRH}$-induced $\mathrm{LH}$ secretion in the presence of medium only or (b) the mean $\pm S$.E. range for follicle diameter at the start of the experiment. Data represent the mean of two different rat pituitary cell culture bioassays for each dose-response curve. Significance values are by ANOVA relative to controls (culture medium only), $* * * P<0.001$. Data are shown as means \pm S.E., $n=2 \times 4$. do not yet express active LH receptors. Our findings, therefore, emphasise that FSH (but not $\mathrm{LH}$ ) is required for GnSAF production by pre-antral follicles.

The difference in the biological effect of secreted proteins from small and large mouse follicles is interesting beyond the observation of decreasing GnSAF production as the follicles grow. The suppression of $\mathrm{GnRH}$-induced LH secretion by proteins secreted from small follicles rather than large ones is further indirect evidence that GnSAF activity is not due to inhibin, since inhibin production increases as mouse follicle cultures progress (Smitz \& Cortvrindt 1998).

The stimulatory effects of proteins from large murine follicles on GnRH-induced LH secretion may possibly be due to the combined effects of increasing activin and decreasing GnSAF bioactivities. The reasoning behind this is that, because activin secretion is known to increase as the follicles grow (Newton et al. 2002) and since activin stimulates GnRH-induced LH secretion from rat pituitary cells (Weiss et al. 1993), conditioned medium from larger follicles would be more likely to stimulate $\mathrm{GnRH}$-induced $\mathrm{LH}$ secretion. In the present study, therefore, the lower doses of conditioned medium might favour the action of activin bioactivity, causing an increase in $\mathrm{GnRH}$-induced $\mathrm{LH}$ secretion. In contrast, at the higher doses of conditioned medium, even though GnSAF bioactivity is reduced, there might be sufficient GnSAF bioactivity present to counteract the stimulatory effects of activin, which could have already exerted its maximal effect at the lower dose of medium. Data in the human suggest that GnSAF production declines rapidly as the follicle grows past $10 \mathrm{~mm}$ in diameter in spontaneously cyclic women (Fowler et al. 2001) or $13 \mathrm{~mm}$ in diameter in women undergoing IVF treatment (Fowler et al. 1994). This represents a decline in GnSAF production post-dominance or following major waves of 


\section{GnSFF bioactivity on each day of culture}

(a) Day 2

(b) Day 3

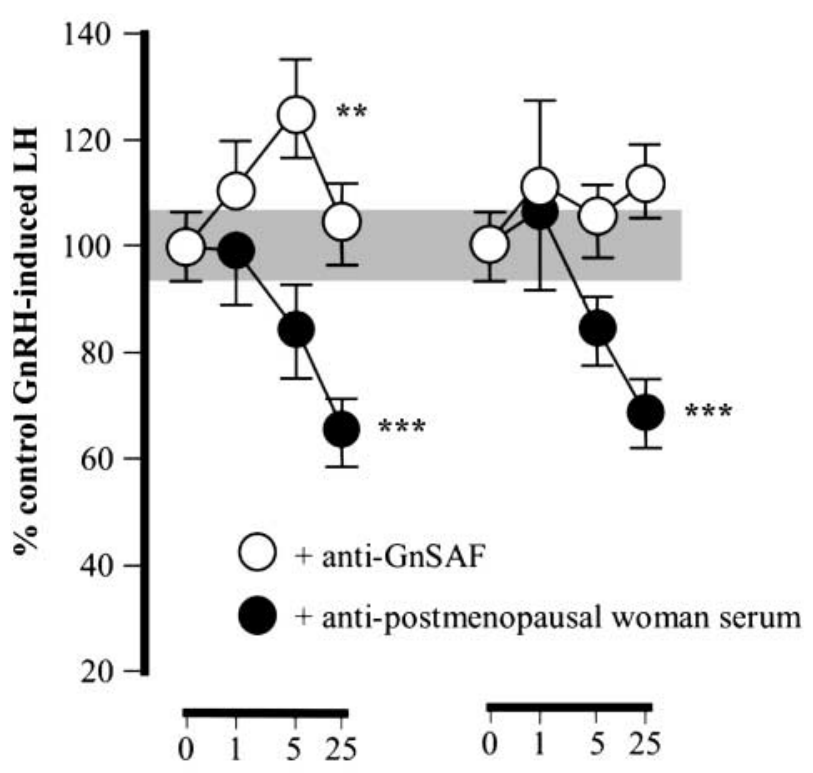

Dose ( $\mu \mathrm{L}$ conditioned medium/well)

Figure 5 Effects of intact rat follicle-conditioned medium collected on days 2 (a) and 3 (b) of culture are blocked following incubation of the conditioned media with anti-human GnSAF pAb (open circles) but not following incubation with anti-postmenopausal woman serum pAb (solid circles). The horizontal shaded bar denotes the mean \pm S.E.M. for $\mathrm{GnRH}$-induced LH secretion in the presence of medium only. Data represent the mean of two different rat pituitary cell culture bioassays for each dose-response curve. Significance values are by ANOVA relative to controls (culture medium only), $* * * P<0.001$. Data are shown as means \pm S.E., $n=2 \times 4$. follicular development (Baerwald et al. 2003) in the human. In the rodent, while there is no evidence for follicular waves, the wave of atresia due to follicle dominance appears to occur around the mid antral stage of development (Baker et al. 2001), with the fall in GnSAF shown here occurring immediately after that. GnSAF production is, therefore, falling as follicles mature towards the pre-ovulatory stage, with a concomitant increase in the production of oestrogens (Spears et al. 1998). Taken together these data are suggestive of the likely role of GnSAF in the rodent. The fact that GnSAF secretion will be highest prior to follicular maturity indicates that the proposal by Fowler et al. (2003) that GnSAF acts to keep LH pulsatility in check is feasible for the rodent. Declining GnSAF production during the last phase of follicular maturation would represent a fall in the overall negative feedback at the level of the pituitary, concomitant with increasing oestradiol secretion and the resulting positive feedback effects on both hypothalamus and pituitary.

The suggestion by Schuiling et al. (1999) that FSH stimulates rat ovarian production of an oestradiol-antagonising factor rather than GnSAF is only one of the two most likely interpretations of their data. The present study clearly demonstrates that FSH treatment of rodent follicles stimulates production of GnSAF bioactivity, and that this bioactivity is completely inhibited by co-incubation with an antibody that blocks human GnSAF (Fowler et al. 2002). This finding also casts doubt on the interpretation of the effects of FSH immunoneutralisation that Tio et al. (1998) reported did not affect the indirectly determined GnSAF bioactivity in rats. (a) 0 IU FSH $/ \mathrm{mL}$

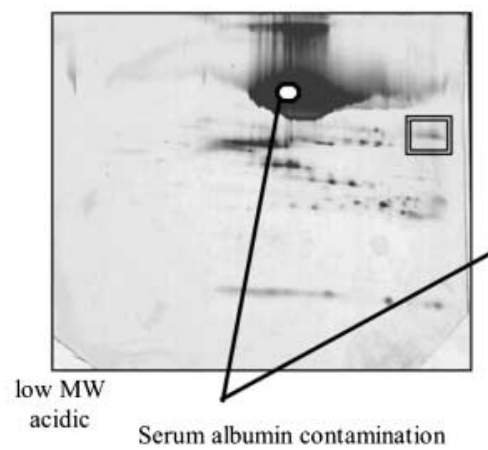

$\square$ Proteins up-regulated by FSH $\square$ Proteins down-regulated by FSH (b) $5 \mathrm{IU}$ FSH $/ \mathrm{mL}$

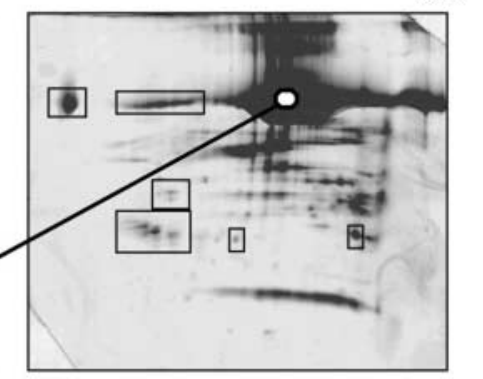

(c) Western blot with anti-human GnSAF pAb

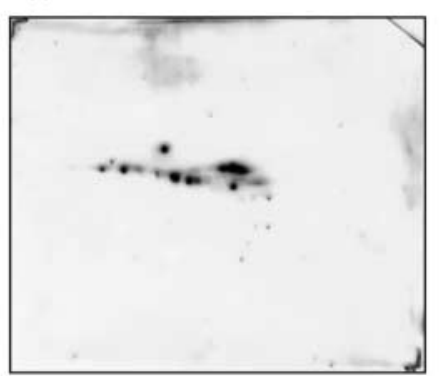

Figure 6 Stimulation of intact rat follicle protein production by in vitro treatment with (a) medium alone and (b) $5 \mathrm{IU} \mathrm{FSH} / \mathrm{ml}$ as shown by 2-D gel electrophoresis. FSH-induced up-regulation of protein production is shown by single-lined boxes, down-regulation by double-lined boxes on the silver-stained gels. In both gels the heavily stained area includes serum albumin. Western blotting with anti-human GnSAF pAb (c) stained several proteins at $\mathrm{pH} 4.5-5.5,50-65 \mathrm{kDa}$. 
It was unfortunate that we were unable to recover sufficient protein to identify some of the proteins secreted in response to FSH treatment, especially those recognised by the anti-GnSAF antiserum. These proteins fell within the expected pl (5.5-5.8 pH) and molecular mass $(60-70 \mathrm{kDa})$ ranges proposed for GnSAF (Fowler et al. 2003) and it would be reasonable to predict that one of them may have been GnSAF. However, this study has clearly demonstrated that the intact rodent follicle culture model is suitable for the investigation of both GnSAF and the regulation of GnSAF production. To investigate the GnSAF molecule itself, a scaling-up of the rat follicle cultures would be required in order to produce sufficient protein for identification using serum protein depletion steps and proteomic techniques. In contrast, with respect to the study of the regulation of GnSAF production, the ability to control steroidal, gonadotrophin and inhibin signalling in the intact follicles and then subsequently determine changes in GnSAF bioactivity would greatly enhance our understanding of the factors regulating GnSAF during the ovarian cycle.

To summarise, the intact rodent follicle culture model demonstrates that GnSAF production is positively regulated by $\mathrm{FSH}$ and preferentially produced by smaller follicles, matching existing GnSAF data for the human in particular.

\section{Acknowledgements}

We thank Mrs M Fraser and Mrs P Cunningham and Rowena Smith for their expert technical assistance. We are grateful to our collaborator Dr P Cash (Department of Medical Microbiology, University of Aberdeen) for performing the 2-D gel electrophoresis. We thank the staff at the Biological Services Unit (University of Aberdeen) for maintaining the rats used in this study and Dr A F Parlow at NIDDK's National Hormone and Pituitary Program (Torrance, CA, USA) and SAPU (Carluke Hospital, Scotland) for hormone assay materials. We are grateful to the BBSRC and MRC for their financial support.

\section{References}

Baerwald AR, Adams PG \& Pierson RA 2003 Characterisation of ovarian follicular wave dynamics in women. Biology of Reproduction 69 1023-1031.

Baker SJ, Srsen V, Lapping R \& Spears N 2001 Combined effect of follicle-follicle interactions and declining follicle-stimulating hormone on murine follicle health in vitro. Biology of Reproduction $651304-1310$.

Cash P, Argo E, Langford PR \& Kroll JS 1997 Development of an Haemophilus two-dimensional protein database. Electrophoresis $181472-1482$.

Cash P, Argo E, Ford L, Lawrie L \& McKenzie H 1999 A proteomic analysis of erythromycin resistance in Streptococcus pneumoniae. Electrophoresis $202259-2268$.

Fowler PA \& Templeton A 1996 The nature and function of putative gonadotropin surge-attenuating/inhibiting factor (GnSAF/IF). Endocrine Reviews 17 103-120.
Fowler PA \& Price C 1997 Follicle-stimulating hormone stimulates circulating gonadotropin surge-attenuating/inhibiting factor bioactivity in cows. Biology of Reproduction 57 278-285.

Fowler PA \& Mason HD 2000 Human granulosa cells secrete gonadotrophin surge-attenuating factor (GnSAF) bioactivity acutely in response to FSH in vitro. Journal of Endocrinology 164 (Suppl.) P243.

Fowler PA, Fraser M, Cunningham P, Knight PG, Byrne B, McLaughlin E, Wardle PG, Hull MGR \& Templeton A 1994 Higher gonadotrophin surge-attenuating factor (GnSAF) bioactivity is found in small follicles from superovulated women. Journal of Endocrinology 143 33-44.

Fowler PA, Sorsa T, Harris WT, Knight PG \& Mason HD 2001 Relationship between follicle size and gonadotrophin surge-attenuating factor (GnSAF) bioactivity during spontaneous cycles in women. Human Reproduction 16 1353-1358.

Fowler PA, Mason HD, Melvin WT, Wilson Y, Cash P, Sorsa-Lesley T \& Harris W 2002 A $60-66 \mathrm{kDa}$ protein with gonadotrophin surge-attenuating factor (GnSAF) bioactivity is produced by human ovarian granulosa cells. Molecular Human Reproduction 8 823-832.

Fowler PA, Sorsa-Lesley T, Harris W \& Mason HD 2003 Ovarian gonadotrophin surge attenuating factor (GnSAF): where are we after 20 years of research? Reproduction 126 689-699.

McGee E, Spears N, Minami S, Hsu SY, Chun SY, Billig H \& Hsueh AJ 1997 Preantral ovarian follicles in serum-free culture: suppression of apoptosis after activation of the cyclic guanosine $3^{\prime}, 5^{\prime}$ monophosphate pathway and stimulation of growth and differentiation by follicle-stimulating hormone. Endocrinology 138 2417-2424.

McGee EA, Smith R, Spears N, Nachtigal MW, Ingraham H \& Hsueh AJ 2001 Mullerian inhibitory substance induces growth of rat preantral ovarian follicles. Biology of Reproduction 64 293-298.

Messinis IE, Lolis D, Papadopoulos L, Tsahalina T, Papanikolaou N, Seferiadis K \& Templeton AA 1993 Effect of varying concentrations of follicle stimulating hormone on the production of gonadotrophin surge attenuating factor (GnSAF) in women. Clinical Endocrinology 39 45-50.

Messinis IE, Lolis D, Papastergiopoulou L, Milingos S, Tsahalina E, Seferiadis K \& Templeton AA 1994 Effect of follicle stimulating hormone treatment on the pituitary response to luteinizing hormone-releasing hormone in post-menopausal women. Human Reproduction $9241-244$.

Murray AA, Molinek MD, Baker SJ, Kojima FN, Smith MF, Hillier SG \& Spears N 2001 Role of ascorbic acid in promoting follicle integrity and survival in intact mouse ovarian follicles in vitro. Reproduction 121 89-96.

Newton H, Wang Y, Groome NP \& Illingworth P 2002 Inhibin and activin secretion during murine preantral follicle culture and following hCG stimulation. Human Reproduction 17 38-43.

Rabilloud T, Valette C \& Lawrence JJ 1994 Sample application by ingel rehydration improves the resolution of two-dimensional electrophoresis with immobilized $\mathrm{pH}$ gradients in the first dimension. Electrophoresis 15 1552-1558.

Schuiling GA, Valkhof N \& Koiter TR 1999 FSH inhibits the augmentation by oestradiol of the pituitary responsiveness to $\mathrm{GnRH}$ in the female rat. Human Reproduction 14 21-26.

Smitz J \& Cortvrindt R 1998 Inhibin A and B secretion in mouse preantral follicle culture. Human Reproduction 13 927-935.

Spears N, Boland NI, Murray AA \& Gosden RG 1994 Mouse oocytes derived from in vitro grown primary ovarian follicles are fertile. Human Reproduction 9 527-532.

Spears N, Murray AA, Allison V, Boland NI \& Gosden RG 1998 Role of gonadotrophins and ovarian steroids in the development of mouse follicles in vitro. Journal of Reproduction and Fertility 113 $19-26$.

Spears N, Baker S, Srsen V, Lapping R, Mullan J, Nelson R \& Allison V 2002 Mouse ovarian follicles secrete factors affecting the 
growth and development of like-sized ovarian follicles in vitro. Biology of Reproduction 67 1726-1733.

Tio S, van Dieten JAMJ \& de Koning J 1998 Immunoneutralization of follicle-stimulating hormone does not affect gonadotrophin surgeinhibiting factor/attenuating factor bioactivity during the rat ovarian cycle. Human Reproduction 13 2731-2737.

Wang Y, Rippstein PU \& Tsang BK 2003 Role and gonadotrophic regulation of $\mathrm{X}$-linked inhibitor of apoptosis protein expression during rat ovarian follicular development in vitro. Biology of Reproduction 68 610-619.
Weiss J, Crowley WF Jr, Halvorson LM \& Jameson JL 1993 Perifusion of rat pituitary cells with gonadotropin-releasing hormone, activin, and inhibin reveals distinct effects on gonadotropin gene expression and secretion. Endocrinology 132 2307-2311.

Received 9 December 2003

First decision 5 March 2004

Accepted 26 March 2004 